\title{
SIGNIFICADOS E SENTIDOS DO TRABALHO: REFLEXÕES PARA A ATUAÇÃO DO MÉDICO DO TRABALHO NA CONTEMPORANEIDADE
}

\author{
MEANINGS AND SENSES OF WORK: REFLECTIONS FOR THE ROLE OF THE \\ OCCUPATIONAL PHYSICIANS IN CONTEMPORANEITY
}

\author{
Maria Luiza Gava Schmidt', Walnei Fernandes Barbosa ${ }^{2}$, \\ Silvia Cristina Camargo Pinceli ${ }^{3}$, Sergio Roberto de Lucca ${ }^{4}$
}

Corresponding author: Maria Luiza Gava Schmidt - Ischmidt@assis.unesp.br 'Psychologist. Postdoctor in Public Health. Professor at the State University Júlio de Mesquita Filho. São Paulo, São Paulo, Brazil. ${ }^{2}$ Occupational physician. Occupational Health and Safety Coordinator at the State University of São Paulo. São Paulo, São Paulo, Brasil. ${ }^{3}$ Occupational nurse. Occupational Health and Medicial Investigation Supervisor at the State University of São Paulo. São Paulo, São Paulo, Brazil. ${ }^{4}$ Occupational physician. PhD in Occupational Health. Professor at the State University of Campinas. Campinas, São Paulo, Brasil.

RESUMO I Introdução: A escolha deste tema se deve ao fato de presenciarmos, nas últimas décadas, transformações importantes no mundo do trabalho como a reestruturação produtiva, as novas formas de gestão e organização, e as novas tecnologias e modelos inovadores que modificam a própria natureza de alguns modos de trabalhar. Objetivo: Apresentar algumas concepções sobre os significados e sentidos do trabalho que possam auxiliar a prática profissional do Médico do Trabalho em diferentes contextos no cotidiano do exercício profissional. Metodologia: Tratase de uma revisão dos conceitos sobre os significados e sentidos do trabalho presentes na literatura com a apresentação das principais abordagens que discorrem sobre esses construtos. Resultados e Discussão: Os referenciais teórico-conceituais que nortearam nossa discussão possuem dispositivos capazes de evidenciar a complexidade do fenômeno estudado e revelam os diferentes modos de pensar a subjetividade nas suas conexões com o trabalho. Todavia, o tema necessita ser estudado em uma perspectiva interdisciplinar, pois a articulação entre os saberes das diferentes disciplinas atuantes no campo da saúde no trabalho poderá contribuir para a reflexão das práticas do Médico do Trabalho no que tange aos fatores de riscos psicossociais no contexto laboral. Conclusão: Conclui-se que, independentemente da perspectiva adotada para esta compreensão entre os significados e sentidos do trabalho, faz-se necessário tomar como referência fundamental um dos elementos essenciais, a subjetividade do trabalhador, componente intrínseco nas relações de trabalho e nos estudos relativos à saúde do trabalhador.

Palavras-Chave: Saúde do Trabalhador, Satisfação no Trabalho, Subjetividade

\begin{abstract}
Introduction: This theme was chosen due to the major transformations witnessed, in recent decades, in the world of work such as productive restructuring, new management and organization methods, and new technologies and innovative models that change the nature of some working modes. Objective: To present some conceptions about the meanings and senses of work that may help the professional role of Occupational Physicians in different contexts in their routine of professional activities. Methodology: This is a review of the concepts about the meanings and senses of the work present in literature with the presentation of the main approaches that address these constructs. Results and Discussion: The theoretical and conceptual references that have guided our discussion include provisions capable of highlighting the complexity of the phenomenon studied and reveal the different ways of thinking the subjectivity in their connections with the work. However, the theme needs to be studied in an interdisciplinary perspective, once the relationship between the knowledge of the various disciplines involved in the field of occupational health will be able to contribute to the reflection of the activities of Occupational Physicians with regard to psychosocial risks factors in the labor context. Conclusion: In conclusion, regardless of the perspective adopted for this understanding among the meanings and senses of work, it is necessary to use as a basic reference one of the essential elements, the subjectivity of the workers, an intrinsic component in labor relations and studies related to the health of workers.
\end{abstract}

Keywords: Occupational Health, Job Satisfaction, Subjectivity 


\section{MEANING AND SENSE OF WORK: ORIGIN OF CONCEPTS AND TERMINOLOGY}

The concept of the meaning of work originated in the 1950s, from studies conducted by the American researchers Morse \& Weiss and Tausky \& Piedmond. However, the concept of the sense of work had as precursors Hackman and Oldhan and the international research team known as Meaning of Work (MOW), in researches conducted in the 1980s (Tolfo, 2015). In the field of psychology, the concept of meaning of work was strengthened at the same time, under the influence of social cognitivism and / or empirical tendencies based on the interrelationship between the individual and society (Borges, AlvesFilho \& Tamayo, 2008).

From a cognitive-constructivist perspective, the meanings attributed to work are components of a subjective process that includes both the individual's history and one's social insertion. Thus, the authors approach the meaning of work as a subjective, sociohistorical and dynamic cognition, being understood as an ongoing process in a changing world and individual and is therefore regarded an unfinished construct (Borges \& Tamayo, 2001).

The definition of sense and meaning of work is permeated in psychology through different epistemological bases, which corroborates the lack of consensus regarding its distinctions and conceptual similarities. In general, although using different terms, authors tend to choose the same study variables, which means that such concepts often approach the point of being treated as synonyms (Borges, AlvesFilho \& Tamayo, 2008; Tolfo \& Piccinini , 2007).

Tolfo and Piccinini (2007) have adopted the concept that relates the concept of meaning to the social understanding of what work is, as sense is representative of a more personal dimension. In addition, they argue that, because it is a multidimensional construct, there is an evident interdependence between both.

Bendassolli \& Guedes Gondim (2014) also point out differentiations between these terms, meaning is an objectification of an interpretation on a given object and sense is a process of singular subjective construction within the shared universe (meaning).
According to these authors, a third axis can be added to these two constructs (the psychological function of work), understood by them as the process of constitution of the subject (of the person) in the interplay between meaning and sense connected by work. Therefore, this triad turns the concept of work into a means for the employee of establishing engagements, of connections with others, with reality, with their own projects and with other activities that are part of their living space (Bendassolli \& Guedes Gondim, 2014).

In addition to being a connector of organization and society's relations, at work there is also room for man-nature relationship, being called by Laurell \& Noriega (1989) the environmental conditions of human collectivities, that forms the walk of life.

Ultimately, it is understood that the meaning of work is a subjective process surrounded by the individual's history and the social insertion of the subject (Borges, Alves-Filho \& Tamayo, 2008). Thus, this subjectivitywork relationship, is characterised by various social markers, such as generation, color, race, ethnicity, rural or urban origin, insertion in private or public organizations, educational level, gender relations, value attributed to work, history and labor market dynamics as well as social-, political-, historical-, and cultural contexts (Nardi, 2015).

In order to understand the meaning and sense of work in these modern times, it should be considered that work, despite going through constant transformations, continues to represent a fundamental value in modern societies, as a source of people's income, self-esteem and achievement, having a significant influence on employee motivation, as well as their satisfaction and productivity (Morin, 2001).

Over the last few decades, we have witnessed important transformations in the field of work that have emerged from new forms of organization, new technologies and innovative models that modify the nature of work. Simultaneously, thousands of people suffer from the fact that they have to work excessively while others suffer from the lack of vacancies (Antunes, 2000).

The diversity of meanings and sense of work determines the way the worker understands his work. 
According to Nardi, Titoni \& Bernardes (2002), "by conceiving the relations between the employee and his work in this way, there is a call to reshape two classic forms of analysis: one that prioritizes the macro provisions of economic developments to describe actions of employees. The other is based on, primarily, psychological analyses, individualization, historically associated with the field of motivation and behavior at work "(p.304).

\section{OCCUPATIONAL HEALTH AND THE IMPORTANCE OF UNDERSTANDING THE MEANING AND SENSE OF WORK IN THE AREA OF EMPLOYEE HEALTH IN MODERN TIMES}

According to Jacques (2002), the introduction of new ways to organize the production process (automation, technological innovations, personnel management policies, etc.) has raised questions about work-identity statements, questions that refer to the impact of these changes on the employee and their expressions of identity in relation to work as well as their own health. Conscious of the inseparability of subjectivity and work and the relevance of this binomial to the constitution of the subject, we consider the identities of the subjects fragmented from the transformations and new demands of work. Within the health-disease process, work interferes in the formation of identity and self-esteem of individuals, being a source of pleasure and satisfaction or of dissatisfaction and illness (Lucca \& Kitamura, 2012).

Understanding the meaning of work today is an important challenge for managers in view of the multiple transformations that have struck organizations and the "worlds of work",8 but in our view this understanding is also necessary in other disciplines, especially Occupational Medicine. In the last decades, the path of Occupation Medicine has led to employee health, through the introduction of practices that require interdisciplinary actions, providing new references in health and work, and the necessity to understand work as a dynamic and social process (Mendes \& Dias, 1991).

There are several theoretical aspects that discuss the analysis of the dynamics of the cognitive and psychologic elements that are elaborated subjectively by employees, improving the understanding of the health-illness process at work. These include: a) Clinic of Activity (Clot, 2006), b) Psychodynamics of Work (Dejours, 1992); c) Psychosociology of Work (Enriquez, 2001; Levy, 2001, Gaulejac, 1997); d) Theory of Mental Wear (Seligmann-Silva, 1994).

Clot (2006) described research instruments which he called the Clinic of Activity, and performed analyses on the subjects' reflections about their own actions within a field of professional activity. In this work, one turns to the subjectivation and the organization of work, pointing out that the social dimension of work is present in the very accomplishment of the work activity, performed in a different way than the task was prescribed.

Dejours (1992) created the slope denominated Psychodynamics of Work, whose theoretical perspective focuses on the analysis of the relationship, pleasure and psychological distress and the defence strategies of employees to prevent the suffering. The author analyses the factors that are playing a part in the relation between men and work that are causing contradictions and disrupting psychological functioning, for example the causes of pleasure and suffering during work activities.

The studies of the Psychodynamics of Work have brought innumerable contributions to the understanding of men - work relations and the processes that lead to alienation, having an important resonance in the understanding of mental health at work, deepening the understanding of Occupational Psychopathology. In the thoughts of Dejours, we find the model of men and subjectivity from the point of view of psychoanalysis.

Psychosociology has as its field of study situations that emerge from groups, organizations and the daily life of communities, as well as the possible links between individuals, and the by those created, managed and transformed ones (Machado, \& Roedel, 2001). In this direction, psychosociology is defined as refusing the cut that creates a division between psychological and social phenomena, understanding that the individual as such does not exist independently of society and its relations (Levy, 2001).

Interventions in the field of Occupational Psychosociology are based on methods in which 
representations, behavior, words, and intersubjective relationships of employees are expressed and they reveal the tensions of daily work that affect and confront the individual and the collective. This requires an analysis of the implicit dynamics of cognitive and psychological elements that are subjectively elaborated by employees.

Seligmann-Silva (1994), when addressing the contribution of psychoanalysis in the field of Mental Health and Work, conceives that:

Psychoanalytic concepts have been the object of an important elaboration, in order to serve the formation of the theories assumably capable of using the analysis of mental suffering connected to work and the origin of this suffering. Psychoanalysis has also contributed through its theory and its technique, to formulate methodologies that have allowed the development of researches that, in recent years, has continuously brought valuable discoveries to the field of work psychopathology. (Page 56)

In this perspective, the author deepens the discussion and formulates the concept of mental exhaustion, focusing on the theme of domination and resistance of workers, bringing relevant contributions to the study of mental health and its psychosocial dimension, especially to the understanding of labor production and the development of mental disorders.

Therefore, independently from the approach to understand the meaning and sense of work, the Occupational Physician, in his practice in the field of employee health, needs to take as key reference one of the essential elements to guide his actions: the subjective perception of the employee. Since the 1700s, when Ramazzini (2000) coined the famous phrase "what arts do you practice" or in the present day "what is your occupation", the concern with classic risk factors that compromise the physical health of workers, such as physical agents (noise and heat) and chemicals (dust, fumes and dust), is present. However, we understand that, in the modern world, in addition to paying attention to these risks, new ways of organizing work require from Occupational Medicine a look at other factors. Especially as psychosocial factors are considered to be the cause of mental illness, which are gradually highlighted in the statistical data as a cause of departing work. This is largely due to the fact that the new ways of working require new skills of the worker and much more knowledge - based on behavioral (intrapersonal) and management skills (decision making and control, teamwork, strategic thinking, among others) according to Veras (2014) - than know-how.

Because of the above, we conclude that the phenomenon of assigning meaning and sense of work can contribute to understand aspects related to worker subjectivity, such as their expectations and desires, that are often constrained by the organization of the work. Considering its complexity, it is perceived that the subject needs to be studied in an interdisciplinary perspective, taking into account the individual and collective scopes, since it is a dynamic construct whose interrelations are displayed in personal and microsocial relations, and particularly in the workplace.

The process of combining the knowledge of the different disciplines that are active in the field of occupational medicine, can contribute to a reflection on traditional practices of risk assessment in Occupational Health. When added to existing knowledge, and management methods in the modern world of work, it could lead to a better understanding of the subject in the context of non-measurable or invisible psychosocial risk factors, improving the traditional instruments of Occupational Health.

The biopsychosocial approach directs the look beyond the physical, even the psychological and social needs, values the subjective perspectives of workers, and contributes to intensification of measures to prevent diseases and improve health in the context of work. Thus, in addition to the question: "What is your occupation", the guiding question that deserves to be included in the practices of the occupational physician (occupational anamnesis, periodic examination, functional evaluation, skills, etc.) should provide information on how the worker feels in their relationship with work. Hence, here's the question: "How are you, in relation to your work"? Quite certainly, while the workers formulate their responses, the meaning and sense they assign to their work will be revealed, subjective perceptions included, which will provide important contributions to the results of the evaluations. 


\section{AUTHOR CONTRIBUTIONS}

Schmidt M LG participated in the study design and conception, literature review, writing and submission to the journal. Barbosa WF participated in the study design and conception, writing and critical review. Spinceli SCC participated in the study design and conception, writing and critical review. Lucca SR participated in the writing and critical review.

\section{COMPETING INTERESTS}

No financial, legal or political competing interests with third parties (government, commercial, private foundation, etc.) were disclosed for any aspect of the submitted work (including but not limited to grants, data monitoring board, study design, manuscript preparation, statistical analysis, etc.).

\section{REFERENCES}

Antunes, R. (2000). Os sentidos do trabalho: ensaio sobre a afirmação e a negação do trabalho. 2 ed. São Paulo: Boitempo.

Bendassolli, P. F., \& Guedes Gondim, S. M. (2014). Significados, sentidos e função psicológica do trabalho: Discutindo essa tríade conceitual e seus desafios metodológicos. Avances en Psicología Latinoamericana, 32(1), 131-147. doi: $10.12804 / \mathrm{apl32.1.2014.09.}$

Borges, L. O., Alves-Filho, A., Tamayo, A. Motivação e significado do trabalho. In Siqueira, M.M.M. et.al (org) Medidas do comportamento organizacional - ferramentas de diagnóstico e gestão (pp.215-248). São Paulo: Artmed.

Borges, L.O., \& Tamayo, A. (2001). A estrutura cognitiva do significado do trabalho. Revista Psicologia Organizações e Trabalho, 1(2), 11 -44. Recuperado em 01 de abril de 2017, de http://pepsic.bvsalud. org/scielo.php?script=sci_arttext\&pid=S1984$66572001000200002 \&$ lng $=$ pt\&tlng $=$ pt.

Clot, Y. (2006). A função psicológica do trabalho. Petrópolis/RJ: Vozes.

Dejours, C. (1992). A Loucura do trabalho. Estudo da psicopatologia do trabalho. São Paulo: Oboré.

Enriquez, E. (2001). O papel do sujeito humano na dinâmica social. In Lèvy, A., Nicolai, A., Enriquez, E., Dubost, J. org e trad. Machado, M. N. M. et al. Psicossociologia: análise social e intervenção (pp.27- 44). Belo Horizonte/MG: Autêntica.

Jacques, M. G. (2002). Identidade e trabalho. In A.D Cattani. (org) Dicionário crítico de trabalho e tecnologia (pp.161165). Petrópolis/RJ: Vozes. trabalho e desgaste operário. Trad. Amélia Cohn et. al. São Paulo: HUCITEC.

Lèvy, A. (2001). A psicossociologia: crise ou renovação? In: Lèvy, A., Nicolal, A., Enriquez, E., Dubost, J. org e trad. Machado M. N. M., et al. Psicossociologia: análise social e intervenção (pp.109-120). Belo Horizonte/MG: Autêntica.

Lucca, S. R., Kitamura, S. (2012). O ensino da Medicina do Trabalho e a importância das visitas aos locais de trabalho. Rev Bras Med Trab, 10(2), 41-8.

Machado, M. N. M.; Roedel, S. (2001) Prefácio. In A. Levy et al. Psicossociologia - análise social e intervenção. In Lèvy, A., Nicolal, A., Enriquez, E., Dubost, J. org e trad. Machado M. N. M., et al. Psicossociologia: análise social e intervenção. Belo Horizonte: Autêntica.

Mendes, R., Dias, E.C. (1991). Da medicina do trabalho à saúde do trabalhador. Rev. Saúde Pública, 25(5): 341-349.

Morin, E.M. (2001). Os sentidos do trabalho. Tradução: Ângelo Soares, Professor de Comportamento Organizacional da Université du Québec à Montréal (UQAM). RAE. Revista de Administração de Empresas, 41(3), 8-19.

Nardi, H. C. (2015). Subjetividade e trabalho. In P.F.Bendassoli .\& J.E.Borges-Andrade (org) Dicionário de psicologia do trabalho e das organizações (pp.635-640). São Paulo: Casa do Psicólogo.

Nardi, H. C., Tittoni J., Bernardes J. S. (2002). Subjetividade e trabalho. In A.D.Cattani (org) Dicionário crítico de trabalho e tecnologia (pp302-308). Petrópolis/RJ: Editora Vozes.

Ramazini, B. (2000). As doenças dos trabalhadores. Trad. de Raimundo Estrela. 3. ed. São Paulo: Fundacentro.

Seligmann-Silva, E. (1994). Desgaste Mental no Trabalho Dominado. Rio de Janeiro: Cortez.

Tolfo, S. R. (2015). Significados e sentidos do trabalho. In P.F Bendassoli \& J.E. Borges- Andrade (org) Dicionário de psicologia do trabalho e das organizações (pp 618-625). São Paulo: Casa do Psicólogo.

Tolfo, S. R., Piccinini, V. (2007). Sentidos e significados do trabalho: explorando conceitos, variáveis e estudos empíricos brasileiros. Psicologia \& Sociedade, 19(spe), 38-46. doi: $10.1590 /$ S0102-71822007000400007

Veras, M. (2014). Gestão de carreiras e competências empresariais - 100 dicas práticas. São Paulo: Atlas.

Laurell, A. C., Noriega, M. (1989). Processo de produção e saúde: 